\title{
Effect of long-term ovariectomy and estrogen replacement on the expression of estrogen receptor gene in female rats
}

\author{
M K Mohamed and A A Abdel-Rahman \\ Department of Pharmacology, School of Medicine, East Carolina University, Greenville, North Carolina, USA \\ (Correspondence should be addressed to A A Abdel-Rahman; Email: rahman@brody.med.ecu.edu)
}

\begin{abstract}
Objective: Estrogen exerts a wide variety of actions involving many target tissues. We studied the effects of long-term ovariectomy (OVX) and OVX with 17 $\beta$-estradiol treatment (OVXE2) on the level of estrogen receptor (ER) gene expression in target tissues of female rats.

Design: Three groups of Sprague-Dawley female rats were utilized in this study: sham operated (SO), OVX and OVXE2.

Methods: SO and OVX were performed 2 weeks before starting the $17 \beta$-estradiol treatment. All groups were maintained on liquid diet for 12 weeks from the time of estradiol treatment. Total RNA was prepared from the tissues of the rats and relative quantitative reverse transcription PCR was utilized to compare the ER $\alpha$-subtype ( $\mathrm{ER} \alpha)$ mRNA level in the three groups for each target tissue.

Results: Following long-term OVX, the levels of ER $\alpha$ expression showed a significant increase in the uterus, kidney and cerebral cortex and no significant change in the liver, cerebellum, brainstem, heart and thoracic and abdominal aorta compared with their SO levels. On the other hand, a 12-week treatment of OVX rats with $17 \beta$-estradiol restored the previously upregulated ER $\alpha$ mRNA to near SO levels except for the liver where the $17 \beta$-estradiol treatment resulted in a significant increase in the $\mathrm{ER} \alpha$ mRNA level compared with that in SO rats.

Conclusions: We conclude that the regulation of ERs by its ligand is tissue specific.
\end{abstract}

Europesn Journal of Endocrinology 142 307-314

\section{Introduction}

Estrogen plays an important role in growth, differentiation and function of many target tissues, including tissues of the female and male reproductive system (1). Estrogen also plays an important role in the maintenance of bone mass and in cardiovascular protection $(2,3)$. To produce its action, estrogen binds to intranuclear receptors known as estrogen receptors (ERs). These receptors are cis-acting transcription factors, members of the steroid receptors superfamily (4). ERs contain three main structural and functional domains; a highly conserved DNA-binding domain located in the middle of the molecule, a less conserved C-terminal ligand-binding domain and a hypervariable $\mathrm{N}$-terminal transactivation domain (5). After binding to its ligand, two molecules of ER dimerize and bind to the specific DNA sequence, estrogen response element, inside the nucleus, followed by activation of target gene transcription (6).

The autoregulation of ER by its ligand has been the subject of many previous studies. In 2 -week ovariectomized (OVX) adult female rats, a single injection of estradiol resulted in more than an $80 \%$ decrease in uterine cytosolic ER binding within $1 \mathrm{~h}$ (7). This decrease in binding was explained in part by nuclear translocation of the receptor after hormone binding. However, this cannot explain the $50 \%$ reduction in the total cellular ER within $1 \mathrm{~h}$ of estradiol injection (8). Estrogen in low doses was shown to upregulate while in high doses it downregulates its receptor in the rat uterus $(9,10)$. In another study, estrogen deficiency downregulated, whereas estrogen and growth hormone administration upregulated intestinal ERs and prevented the OVX-induced decrease in receptor binding affinity (11). Zou \& Ing (12) reported that estradiol upregulates ER mRNA in endometrium, but downregulates it in the liver. In contrast, estrogen upregulates ER in the liver of Xenopus laevis (13). In rat bone, there was a sharp decrease in ER mRNA level when estrogen was reduced after OVX and the expression of bone ER mRNA increased during estradiol therapy (14).

In this study we investigated the long-term effects of OVX and estrogen replacement on ER gene expression in different rat tissues including the heart, thoracic and abdominal aorta, cerebral cortex, brain stem and cerebellum. The choice of these tissues was based on our interest in studying the effects of estrogen and consequent changes in ERs in cardiovascular tissues and brain areas that control blood pressure. For 
comparison, we studied some of the $\mathrm{ER} \alpha$ gene expression in non-cardiovascular tissues such as the uterus, liver and kidney.

\section{Materials and methods}

\section{OVX}

Female Sprague-Dawley rats (9-10 weeks old; Harlan, Indianapolis, IN, USA) were employed in this study. Bilateral OVX was performed as described in our previous studies and others (15-17). Briefly, the rat was anesthetized using methohexital $(50 \mathrm{mg} / \mathrm{kg}$ i.p). The lower part of the back skin was shaved and a single $2-3 \mathrm{~cm}$ incision was made in the skin to expose the back muscles. A small $1-2 \mathrm{~cm}$ incision was made in the muscles overlying the ovaries on both sides and the ovaries were isolated, tied off with sterile suture and removed. The muscles and the skin were sutured separately, and the rats were allowed to recover for approximately 2 weeks before the time of the experiment. Sham operation (SO) was performed by exposing the ovaries without isolation. Following OVX or SO, each rat received an s.c. injection of buprenorphine hydrochloride (Buprenex; $30 \mu \mathrm{g} / \mathrm{kg}$ ) to control pain and an i.m. injection of $50000 \mathrm{U} / \mathrm{kg}$ of penicillin $\mathrm{G}$ benzathine and penicillin $G$ procaine in an aqueous suspension (Durapen) and was housed in a separate cage. All surgical procedure and post-operative care were done in accordance with the institutional guidelines for animal care and use.

Two weeks after OVX, 17 $\beta$-estradiol, $1.7 \mathrm{mg} /$ pellet, 120-day release (Innovative Research of America, Sarasota, FL, USA) was implanted s.c. in some of the OVX rats to form a $17 \beta$-estradiol-treated OVX group (OVXE2). Rats of the SO and OVX groups received control pellets s.c. (placebo for $17 \beta$-estradiol).

\section{Diets}

The three groups of rats were maintained on Leiber DeCarli high protein liquid diet \#710029 (Dyets, Bethlehem, PA, USA). The daily intake was adjusted so that each rat in the three groups consumed an equal amount of the liquid diet when compared with other rats.

\section{Total RNA preparation}

At the end of the study, rats from different groups were killed by decapitation, tissues were immediately removed, frozen in liquid nitrogen and stored at $-80^{\circ} \mathrm{C}$ until used. A total of 33 rats, divided into three groups $(n=11$ each), were employed in the present study. The sample size varied between four and eight due to the loss of some samples. Thawed tissues (100-200 mg) were homogenized in 1-2 ml TRIzol reagent (Life Technologies, Gaithersburg, MD,
USA) and total RNA was prepared according to the manufacturer's instructions.

\section{DNase I digestion of RNA preparation}

To eliminate residual genomic DNA from the RNA sample and avoid artificial amplification in reverse transcription PCR (RT-PCR), $3 \mu \mathrm{g}$ total RNA from each sample were digested with 2 units of amplification grade DNase I (Life Technologies) in a reaction mix containing $20 \mathrm{mmol} / \mathrm{l}$ Tris-HCl (pH 8.4), $50 \mathrm{mmol} / \mathrm{l} \mathrm{KCl}$, and $2 \mathrm{mmol} / \mathrm{l} \mathrm{MgCl}_{2}$ in diethyl pyrocarbonate-treated $\mathrm{H}_{2} \mathrm{O}$ to a final volume of $10 \mu \mathrm{l}$. The reaction was incubated at room temperature for $15 \mathrm{~min}$ and stopped by the addition of $1 \mu \mathrm{l} 25 \mathrm{mmol} / \mathrm{l}$ EDTA and incubation at $65^{\circ} \mathrm{C}$ for another $15 \mathrm{~min}$.

\section{Relative quantitative RT-PCR}

The previously DNase I-digested RNA samples were used for the first-strand cDNA synthesis using random hexamers and the SuperScript Preamplification system kit (Life Technologies) according to the manufacturer's instruction manual. Briefly, $100 \mathrm{ng}$ of the random hexamers were incubated with the DNase I-digested RNA samples at $70^{\circ} \mathrm{C}$ for $10 \mathrm{~min}$. A reaction mix containing $2 \mu \mathrm{l} 10 \times$ PCR buffer, $2 \mu \mathrm{l} 25 \mathrm{mmol} / \mathrm{l} \mathrm{MgCl}_{2}$, $1 \mu \mathrm{l} 10 \mathrm{mmol} / \mathrm{l} \mathrm{dNTP} \operatorname{mix}$ and $2 \mu \mathrm{l} 0.1 \mathrm{~mol} / \mathrm{l}$ dithiothreitol was then added to each RNA/primer and incubated at room temperature for $5 \mathrm{~min}$. One microliter (200 units) of SuperScript II (Life Technologies) reverse transcriptase enzyme was then added to each tube, mixed, incubated at room temperature for $10 \mathrm{~min}$ and at $42{ }^{\circ} \mathrm{C}$ for $50 \mathrm{~min}$. The reaction was stopped by incubation at $70^{\circ} \mathrm{C}$ for $15 \mathrm{~min}$. The RNA hybrid with the newly synthesized cDNA in each sample was then digested by incubation with $1 \mu \mathrm{l}$ ( 1 unit) of $E$. coli RNase $\mathrm{H}$ at $37^{\circ} \mathrm{C}$ for $20 \mathrm{~min}$.

The relative quantitative PCR was then assembled for each sample by adding $2 \mu \mathrm{l}(1 / 10)$ of the cDNA sample reaction to $5 \mu \mathrm{l} 10 \times \mathrm{PCR}$ buffer, $3 \mu \mathrm{l} 25 \mathrm{mmol} / \mathrm{l} \mathrm{MgCl}_{2}$, $1 \mu \mathrm{l} 10 \mathrm{mmol} / \mathrm{l} \mathrm{dNTPs}, 5 \mu \mathrm{M}$ of ER $\alpha$-specific primers, $2.5 \mu \mathrm{l} 18 \mathrm{~S}$ primers/competimers (4:6) (Ambion Inc., Austin, TX, USA), 1.5 units of thermophilic polymerase and double-distilled $\mathrm{H}_{2} \mathrm{O}$ to a final volume of $50 \mu \mathrm{l}$. The PCR mixture was supplemented with $1-2 \mu \mathrm{Ci}$ $\left[\alpha_{-}{ }^{32} \mathrm{P}\right] \mathrm{dCTP}(10 \mathrm{mCi} / \mathrm{ml}, \sim 3000 \mathrm{Ci} / \mathrm{mmol}$; Amersham, Arlington Heights, IL, USA) for labeling and better detection of the PCR products. The ER $\alpha$-specific primers used for PCR amplification were, S1 (sense, -16 relative to ATG: 5'- GCGGCTGCCACTGACCATG) and AS2 (antisense, +169 relative to ATG: 5' - CCTCGGGGTAG TTGAACACGG) (18) allowing the amplification of a $185 \mathrm{bp}$ fragment corresponding to the $5^{\prime}$ non-coding region and to the first part (N-terminal) of the coding region of rat ER gene (19). The amplification was performed in a GeneAmp 2400 (Perkin Elmer, Foster City, CA, USA), and consisted of 25 cycles (30 s of 
denaturation at $94^{\circ} \mathrm{C}, 30 \mathrm{~s}$ of annealing at $55^{\circ} \mathrm{C}$, and $45 \mathrm{~s}$ elongation at $72^{\circ} \mathrm{C}$ ), with a final elongation at $72{ }^{\circ} \mathrm{C}$ for $9 \mathrm{~min}$. Four percent non-denaturing PAGE was utilized to analyze the PCR products. The gel was then dried and exposed to X-ray film.

\section{Estradiol measurement}

Weekly blood samples were collected from the rats under study. EDTA plasma was separated by centrifugation and stored at $-20{ }^{\circ} \mathrm{C}$ until the time of measurement. The estradiol level in the samples was measured using an Estradiol DSL-4400 Radioimmunoassay kit (Diagnostic Systems Laboratories, Inc., Webster, TX, USA) according to manufacturer's instructions.

\section{NIH image analysis}

Analysis of the bands was performed on a power Macintosh 7300/180 computer using the public domain NIH Image program (developed at the US National Institutes of Health). A gel-plotting macro was used to outline the bands and the area underneath the curve was calculated. The intensity was calculated on the uncalibrated OD setting. The area representing the $\mathrm{ER} \alpha$ band over the area representing the $18 \mathrm{~S}$ ribosomal RNA band $(\mathrm{ER} \alpha / 18 \mathrm{~S} \mathrm{RNA})$ for tissues from the SO rats was taken as a control and representing a $100 \%$ expression level. The percentage $\mathrm{ER} \alpha / 18 \mathrm{~S}$ RNA of OVX or OVXE2 rats compared with that of the SO rats represents the response of $\mathrm{ER} \alpha$ expression in the tissues examined elicited by OVX and OVXE2, respectively.

\section{Statistical analysis}

Values are expressed as mean士s.E.M. An ANOVA followed by a Newman-Keuls post-hoc analysis was used for multiple comparisons. Student's t-test was used in the analysis of paired and unpaired data with the level of significance set at $P<0.05$.

\section{Results}

\section{Plasma estradiol level}

During the first 6 weeks, the plasma estradiol level was very high in the OVXE2 group, which had received the s.c. slow release pellets. However, plasma estradiol level declined to physiological values by weeks 10-12 $(34.7 \pm 5.7 \mathrm{pg} / \mathrm{ml}$ in weeks 10-12). The estradiol level was low in OVX rats throughout the study, with an average of $8.8 \pm 1.1 \mathrm{pg} / \mathrm{ml}$ during weeks $10-12$. In the SO group, the level of estradiol was fluctuating with increases and decreases according to the number of rats that happened to be in the proestrus phase of the estrous cycle. In general, the estradiol level in the SO group was higher than in OVX but lower than in the OVXE2 groups, with a 10-12 weeks average level of $13.8 \pm 2.4 \mathrm{pg} / \mathrm{ml}$.

\section{Gain in body weight following OVX and OVXE2}

OVX rats gained an average of $40 \mathrm{~g}$ in body weight compared with their age- and weight-matched SO rats. As shown in Fig. 1, following s.c. implantation of the $17 \beta$-estradiol pellets, there was a sharp decrease in body weight within 1 week in the OVXE2 rats, which maintained an average body weight comparable with, but slightly lower than, that of the SO rats. Following the rapid weight gain that occurred early after OVX, the increase in weight was gradual (Fig. 1). The difference in body weight, between the OVX group on the one hand and the SO and OVXE2 groups on the other hand, was maintained throughout the whole period of the study (Fig. 1).

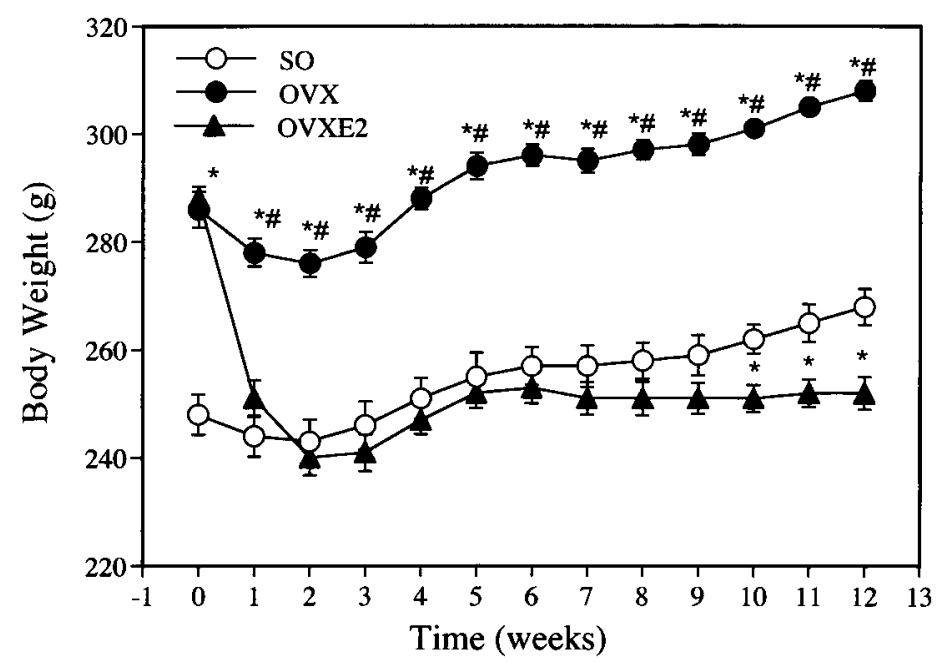

Figure 1 The effect of OVX and estrogen replacement on gain in body weight. OVX $(n=11)$ or SO $(n=11)$ was performed 2 weeks before starting estrogen treatment (OVXE2) $(n=11)$. * and $\# P<0.05$ compared with SO and OVXE2 respectively. 


\section{Uterine ER $\alpha$ gene expression}

The uterus, as the main target organ for estrogen, was the first tissue to be examined and was taken as a reference for the long-term effects of OVX or OVXE2 on $\mathrm{ER} \alpha$ gene expression. After total RNA extraction from the uterine tissue, RT-PCR was used to amplify the ER $\alpha$ message using gene-specific primers. $18 \mathrm{~S}$ ribosomal RNA was used as an internal standard and for adjustment of sample-to-sample variations. Compared with the SO group (taken as $100 \%$ ), the $\mathrm{ER} \alpha$ gene expression was significantly $(P<0.001)$ higher $(212 \pm$ $23.9 \%)$ and lower $(77 \pm 6.4 \%)$ in the OVX and OVXE2 groups respectively (Fig. 2A and B). This finding shows that there is upregulation of the $\mathrm{ER} \alpha$ subtype in response to long-term OVX in rat uterine tissue and that the chronic administration of estrogen downregulates the receptor at the transcription level.

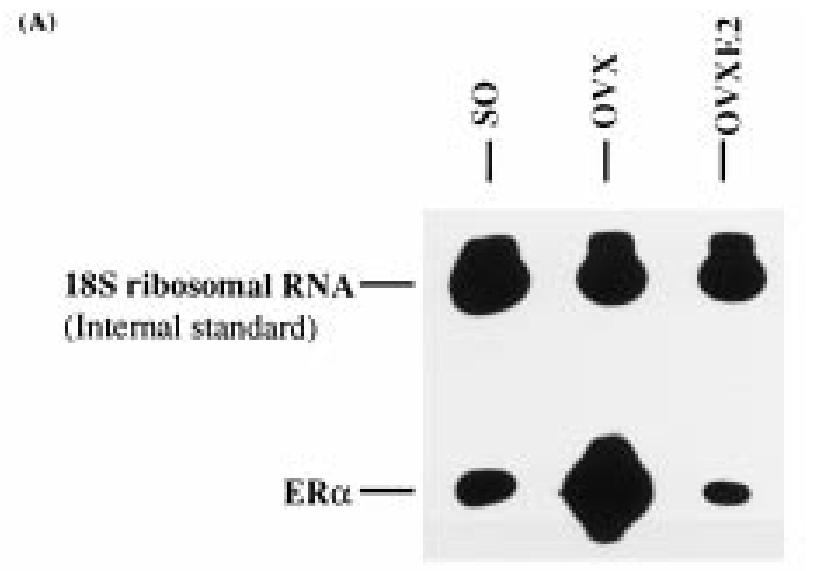

(B)

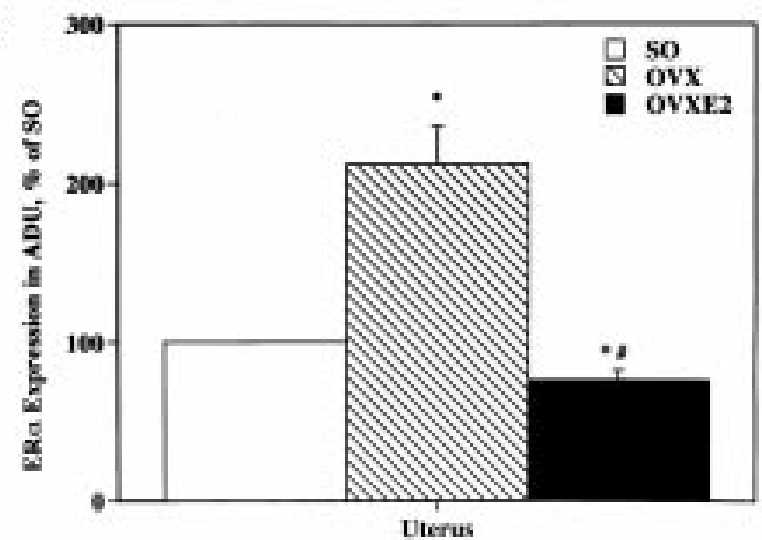

Figure 2 The expression of $E R$ in rat uterus. (A) A 4\% nondenaturing PAGE showing the $\left[\alpha^{-}{ }^{32} \mathrm{P}\right] \mathrm{dCTP}$-labeled RT-PCR products of ER of SO, OVX and OVXE2 female rats in relation to $18 \mathrm{~S}$ ribosomal RNA (the internal standard). (B) A bar graph representing the changes in ER expression level in OVX $(n=8)$ and OVXE2 $(n=8)$ rats in arbitrary densitometric units (ADU) as percent of SO rat levels (taken as $100 \%$ ). ${ }^{*} P<0.001$ and $<0.005$ for OVX and OVXE2 respectively compared with $\mathrm{SO}(n=8)$. \#P<0.001 for OVXE2 compared with OVX.

\section{Variable expression of ER $\alpha$ in liver and kidney}

Estrogen deficiency following OVX resulted in a significant increase $(P<0.025)$ in the level of $\mathrm{ER} \alpha$ gene expression in the kidney $(273.5 \pm 61.2 \%$ of control), but no significant change $(103.0 \pm 13.1 \%$ of control) was detected in the liver (Fig. 3A and B). Treatment of OVX rats with $17 \beta$-estradiol reduced the gene expression of $\mathrm{ER} \alpha$ in the kidney to control level (118.0 $\pm 27.2 \%$ of control). On the other hand, there was a significant $(P<0.05)$ increase $(137.7 \pm 13.9 \%$ of control) in the gene expression of $\mathrm{ER} \alpha$ in the liver of OVXE2 rats.

\section{Expression of ER $\alpha$ in cardiovascular tissues}

The effects of estrogen depletion and replacement were also studied in cardiovascular tissues (the heart and
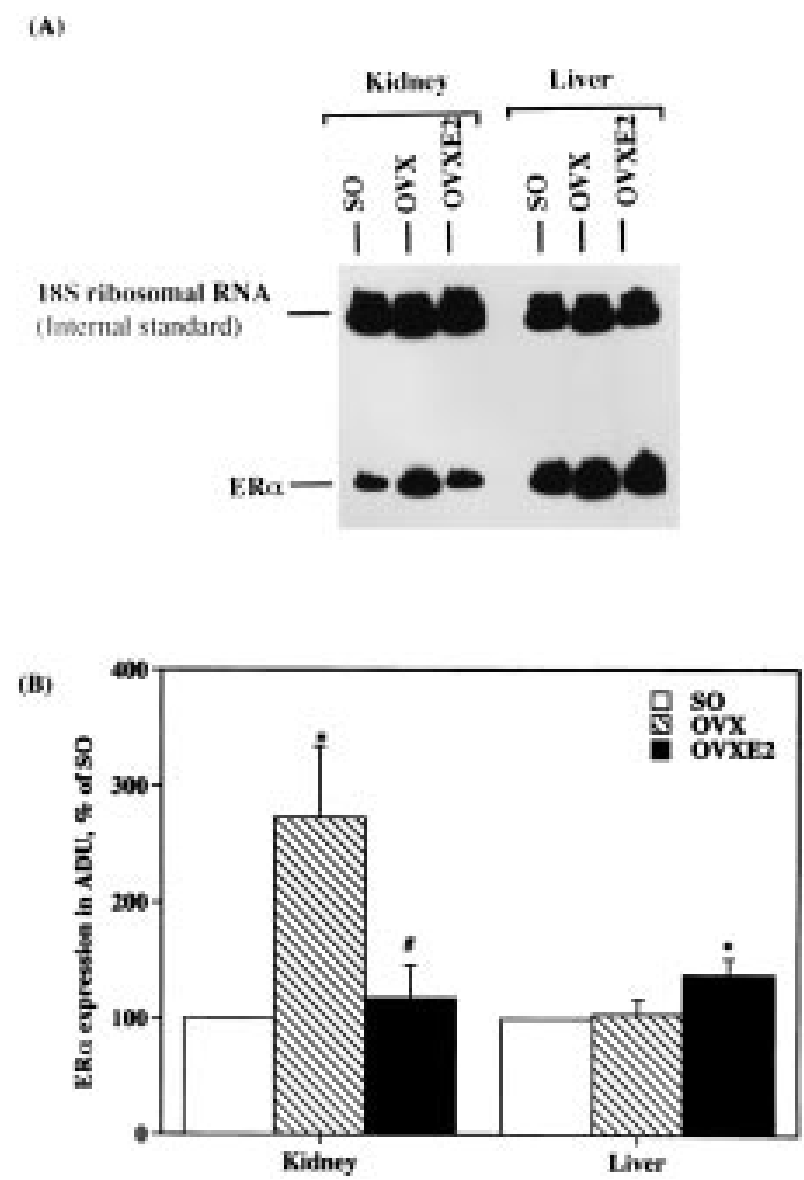

Figure 3 The expression of ER in female rat kidney and liver. (A) A $4 \%$ non-denaturing PAGE showing RT-PCR products of ER of SO, OVX and OVXE2 rats in relation to 18S ribosomal RNA (the internal standard) in both liver and kidney. (B) A bar graph representing the changes in ER expression level in kidney and liver of OVX $(n=5)$ and OVXE2 $(n=5)$ rats in arbitrary densitometric units (ADU) as percent of SO rat $(n=5)$ levels (taken as $100 \%)$. ${ }^{*} P<0.02$ for OVX compared with SO. $\# P<0.05$ for OVXE2 compared with OVX. 
(A)
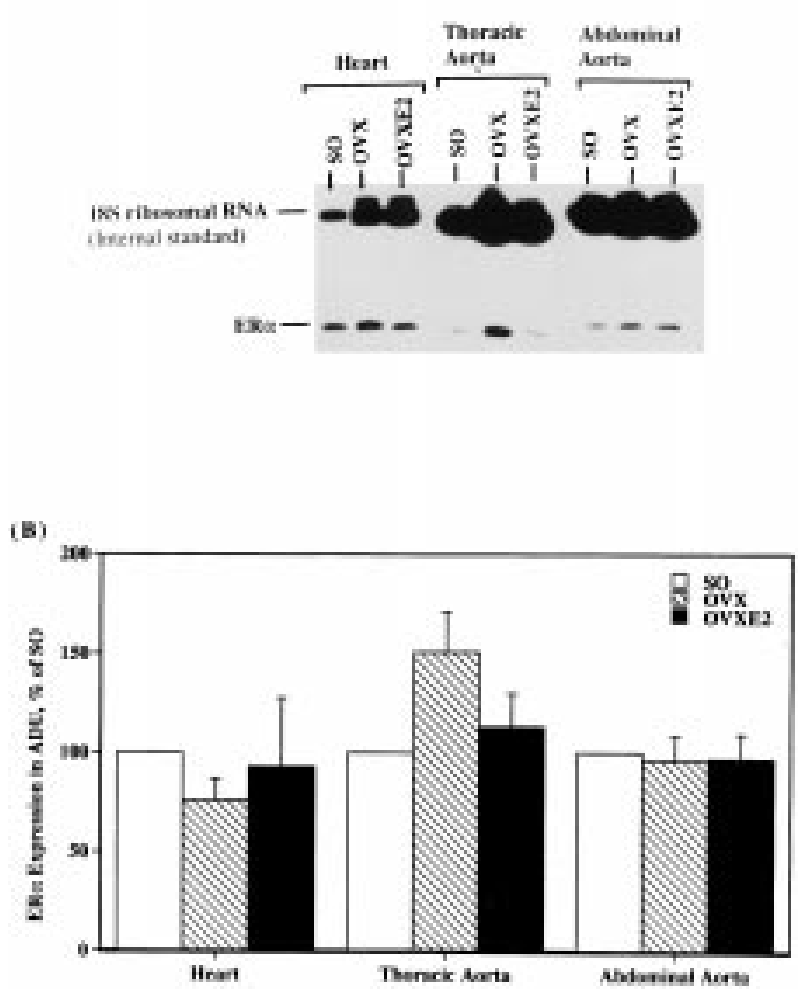

Figure 4 The expression of ER in rat cardiovascular tissues. (A) The RT-PCR products of ER of SO, OVX and OVXE2 rats from heart ( $n=5$ each), and thoracic ( $n=4$ each) and abdominal aorta $(n=7)$ in relation to the internal standard (18S ribosomal RNA) were separated on a $4 \%$ non-denaturing gel electrophoresis. (B) The changes of ER expression level of OVX and OVXE2 rat heart, and thoracic and abdominal aorta represented in arbitrary densitometric units as percent of SO rat levels. No significant changes were detected.

thoracic and abdominal aorta) (Fig. 4A and B). Following long-term OVX, there was a non-significant reduction in the expression level of $\mathrm{ER} \alpha$ in the heart $(76.0 \pm 10.7 \%$ of SO level) and abdominal aorta $(96.1 \pm$ $12.3 \%$ of SO level) and a non-significant increase $(151.0 \pm 20.2 \%$ of SO level) in thoracic aorta. The latter did not achieve statistical significance because of variability of the responses. On the other hand, longterm treatment of OVX rats with $17 \beta$-estradiol reversed the effects of OVX on the expression level of ER $\alpha$ in the heart $(93.0 \pm 34.7 \%$ of SO level) and thoracic aorta $(113.0 \pm 17.1 \%$ of SO level) but had no effect on the expression level in the abdominal aorta $(97.1 \pm 12.1 \%$ of SO level).

\section{Expression of ER $\alpha$ in brain tissues}

As shown in Fig. 5A and B, long-term OVX resulted in a significant $(P<0.05)$ increase in the level of expression of $\mathrm{ER} \alpha$ in cerebral cortex $(123 \pm 8.0 \%)$ and a non-significant increase $(129 \pm 15.9 \%)$ in brainstem
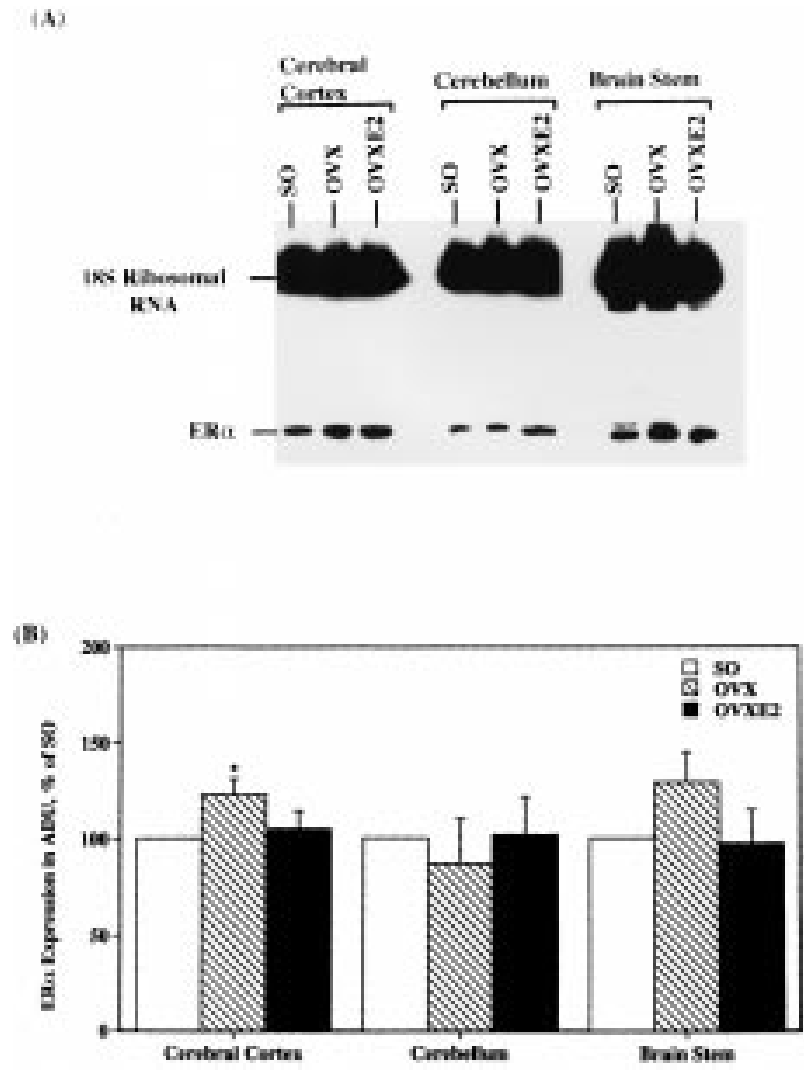

Figure 5 ER expression in rat brain tissues ( $n=4$ for each group). As represented in the gel electrophoresis $(A)$ and the bar graph (B), the only significant change was the increase in expression level of ER in cerebral cortex of OVX compared with SO rats $\left({ }^{\star} P<0.05\right)$.

compared with their SO levels respectively. The latter did not achieve statistical significance because of the inter-individual variability of the responses. In cerebellum, there was a non-significant decrease in the $\mathrm{ER} \alpha$ expression level $(87 \pm 23.5 \%$ compared with SO rat levels). $17 \beta$-Estradiol had no significant effect on the $\mathrm{ER} \alpha$ expression in cerebral cortex, brainstem and cerebellum. Comparison of the level of ER $\alpha$ expression in the three brain tissues of the SO group revealed tissue-dependent distribution of $\mathrm{ER} \alpha$ (Fig. 6). The cerebral cortex and brainstem contained higher levels of $\mathrm{ER} \alpha$ when compared with the cerebellum in the same group of rats (Fig. 5A and B).

\section{Discussion}

Post-menopausal women are at increased risk for many health problems such as cardiovascular diseases and osteoporosis compared with premenopausal women or even with age-matched males (20). The main difference is the deficiency of the ovarian hormones, especially estrogen, in post-menopausal women. Previous studies investigated the changes in ER gene expression in one or more tissues, but this was done under estrogen depletion or treatment for a short 


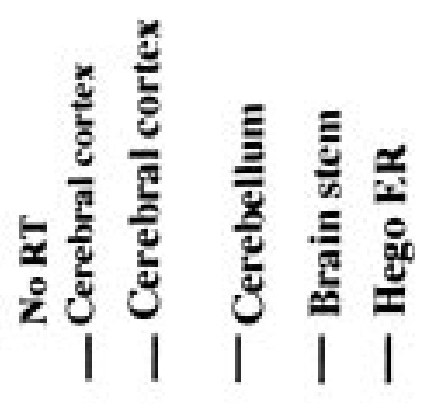

$18 \mathrm{~S}$ ribsomal RNA -

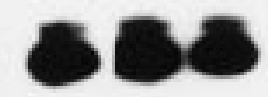

ER $\alpha$ mRNA -

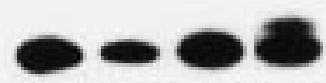

Figure 6 A 4\% non-denaturing gel electrophoresis showing the variable level of expression of ER in different parts of the brain of SO rats. The cerebellum shows a lower level of ER compared with the cerebral cortex and brainstem. No RT, no reverse transcriptase was added; Hego ER, plasmid containing wild-type ER DNA sequence used as a positive control.

period of time. In this study, we investigated the longterm effects of OVX (surgical menopause) and estrogen replacement on ER gene expression in different tissues of the female rat. In our study two model systems were used: a 12-week OVX and OVXE2.

Reduction in ovarian hormones following OVX resulted in a significant increase in body weight, while $17 \beta$-estradiol treatment restored the body weight of OVX to SO levels. This result agrees with many previous studies $(21,22)$. The present study showed that estrogen depletion (OVX) for 12 weeks resulted in an increase in the ER mRNA compared with that in SO rats. On the other hand, estrogen replacement restored uterine $\mathrm{ER} \alpha$ mRNA in OVXE2 rats to levels similar to those of the SO group. These results agree with the results of Rosser et al. (23), who showed that OVX for 14 days brought about a 3-fold increase in rat uterine ER mRNA levels and these levels were decreased by a 3-day treatment with $2 \mu \mathrm{g}$ estradiol in ethanol/saline injected i.p. In their study, estrogen treatment decreased the ER mRNA to levels lower than in the OVX group, but the level was still significantly higher compared with intact animal levels. The difference in the responses to estradiol treatment between the two studies may be attributed, at least in part, to the short duration of estrogen treatment in their study (3 days) compared with 12 weeks in our study.
The existence of ER in mammalian livers was reported in previous studies (24). The liver contains only $\operatorname{ER} \alpha$ with no $\operatorname{ER} \beta$ detected (25). In our study, using the relative quantitative RT-PCR, we detected the presence of $\mathrm{ER} \alpha$ in female rat liver. No significant changes were seen in the ER mRNA levels after longterm estrogen deprivation (OVX) for 12 weeks compared with those in SO rats. In OVXE2 rats, there was a significant increase in the ER mRNA levels compared with those in SO rats. In a previous study (26), androgens showed a negative regulatory influence, while estrogens and adrenal and thyroid hormones did not influence the regulation of hepatic ER mRNA in rats. Our results do not support the reported finding and partially agree with the reported findings by Shupnik et al. (27) where liver ER mRNA declined 1.5- to 3-fold after OVX and returned to intact levels after 1-3 days of estradiol replacement. This may be explained by the difference between the studies in the duration of OVX (3-4 weeks in their study compared with 12 weeks in ours) and estrogen treatment (daily injection with $17 \beta$ estradiol for a maximum of 7 days compared with 12 weeks of slow release pellets of $17 \beta$-estradiol in our study). We also used a more sensitive technique, RTPCR, which is not dependent on detecting full-length receptor but can still detect partially degraded mRNA so long as this degradation does not involve the sequence of interest. Using the hydroxylapatite assay, Spano et al. (28) reported an increase in the concentration of hepatic ER in gonadectomized male and female rats compared with that in intact rats.

To our knowledge, this is the first study to investigate the effect of estrogen deprivation and replacement on the ER $\alpha$ gene expression in the kidney. The ER $\alpha$ mRNA level in the kidney showed variation similar to that seen in the uterus, with upregulation and increased expression of $\mathrm{ER} \alpha$ with estrogen deprivation in ovariectomized rats. With estrogen replacement, the ER $\alpha$ expression decreased to levels similar to those seen in the SO control group.

The existence of functional ERs in human vascular smooth muscle cells (29) and myocardial and myogenic cells $(30,31)$ has been reported. In the present study, the changes in $\mathrm{ER} \alpha$ expression were non-significant in the heart, thoracic aorta and abdominal aorta following OVX or $17 \beta$-estradiol replacement. It seems unlikely that the mechanisms by which estrogen produce its cardiovascular protective effects may involve changes in the $\mathrm{ER} \alpha$ gene expression in the tissues examined. A possible mechanism may involve reduction of circulating levels of both angiotensin-converting enzymes (32) by estrogen treatment. Direct effects on cardiac cells through activation of other genes or other subtypes of the ER may be another mechanism of action for estrogen.

Three different areas of the brain, cerebral cortex, cerebellum and brainstem, were examined for the expression of $\mathrm{ER} \alpha$ and their response to estrogen 
deprivation or treatment. The expression level of ER $\alpha$ was higher in cerebral cortex and brainstem compared with that in cerebellum. The $\mathrm{ER} \alpha$ expression was significantly upregulated following OVX in the cerebral cortex. No significant changes were observed in the brainstem or cerebellum.

It is important to comment on the relevance of estrogen-mediated changes in ER gene expression to the biological actions of estrogen. For example, the findings on brainstem $\mathrm{ER} \alpha$ expression are surprising, given our recent findings that estradiol enhances baroreflex sensitivity via a central site of action (15). It is possible that estradiol action involves non-transcription pathways or the other ER receptor isoform, $\mathrm{ER} \beta$, which is expressed in the brainstem (33). Recent evidence suggests that the differential distribution of ER proteins denoting the $\mathrm{ER} \alpha$ and $\mathrm{ER} \beta$ subtypes may explain specific cellular actions of estradiol in some tissues $(30,31,34)$. Two recent findings suggest that some biological effects of estrogen may be dependent on one, but not the other, ER isoform. First, the induction of galanin gene expression in the pituitary of the mouse by estrogen is dependent on the presence of functional $\mathrm{ER} \alpha$ (35). Second, the presence of functional ER $\beta$ in the rat cortex is essential for the expression of the neuroprotective action of estrogen observed in a model of cerebral ischemia (36). Taken together, the present findings suggest that brainstem $\mathrm{ER} \alpha$ does not seem to play a crucial role in estrogen-evoked enhancement of baroreflex activity. It is possible that this favorable effect of estrogen is dependent on $\operatorname{ER} \beta$ or may involve a nontranscriptional action of estrogen. Future studies are warranted to address this issue.

In conclusion, our results show that the regulation of ER gene expression by estrogen deprivation or treatment is tissue specific. Knowledge of the expression level of ER in different tissues may be valuable for the understanding of the mechanism of action underlying the different responses to estrogen agonists and/or antagonists in a tissue-specific manner.

\section{Acknowledgements}

This work was supported by Grant AA10257 from the National Institute on Alcohol abuse and Alcoholism to A A R. We also would like to thank Ms Swarooparani Vadlamudi for her technical assistance.

\section{References}

1 Tsai M-J, Clark JH, Schrader WT \& O’Malley BW. Mechanisms of action of hormones that act as transcription regulatory factors. In Williams Textbook of Endocrinology, edn 9, ch 4, pp 55-94. Eds JD Wilson, DW Foster, HM Kronenberg \& PR Larsen. Philadelphia: WB Saunders, 1998.

2 Turner RT, Riggs BL \& Spelsberg TC. Skeletal effects of estrogen. Endocrine Reviews 199415 275-300.

3 Farhat MY, Lavigne MC \& Ramwell PW. The vascular protective effects of estrogen. FASEB Journal $199610615-624$.
4 Evans RM. The steroid and thyroid hormone receptor superfamily. Science $198824014062-14064$.

5 Mangelsdorf DJ, Thummel C, Beato M, Herrlich P, Schutz G, Umrsono K, Blumberg B, Kastner P, Mark M, Chambon P \& Evans RM. The nuclear receptor superfamily: overview of the second decade. Cell 199583 835-839.

6 Tsai M-J \& O'Malley BW. Molecular mechanisms of action of steroid/thyroid receptor superfamily members. Annual Review of Biochemistry 199463 451-486.

7 Cidlowki JA \& Muldoon TG. The dynamics of intracellular receptor regulation as influenced by $17 \beta$-estradiol. Biology of Reproduction 197818 234-246.

8 Copland JA, Smanik EJ \& Muldon TG. Discrete early changes in cellular subpopulations of rat uterine and anterior pituitary estrogen receptors in response to acute exposure to exogenous estradiol. Journal of Steroid Biochemistry 198726 583-588.

9 Medlock KL, Forrester TM \& Sheehan DM. Short-term effects of physiological and pharmacological doses of estradiol on estrogen receptor and uterine growth. Journal of Receptor Research 199111 743-756.

10 Medlock KL, Forrester TM \& Sheehan DM. Progesterone and estradiol interaction in the regulation of rat uterine weight and estrogen receptor concentration. Proceedings of the Society for Experimental Biology and Medicine 1994205 146-153.

11 Chen C \& Kalu DN. Modulation of intestinal estrogen receptor by ovariectomy, estrogen and growth hormone. Journal of Pharmacology and Experimental Therapeutics 1998286 328-333.

12 Zou K \& Ing NH. Estradiol up-regulates estrogen receptor, cyclophilin, and glyceraldehyde phosphate dehydrogenase mRNA concentrations in endometrium, but down-regulates them in liver. Journal of Steroid Biochemistry and Molecular Biology $199864231-237$.

13 Barton M \& Shapiro D. Transient administration of $17 \beta$ estradiol establishes an autoregulatory loop permanently inducing estrogen receptor mRNA. Proceedings of the National Academy of Sciences of the USA $1988857119-7123$.

14 Li W, Huang F \& Tan Y. Detection of estrogen receptor messenger ribonucleic acid in normal and ovariectomized rat bone. Chung Hua Ping Li Hsueh Tsa Chih 199524 312-314.

15 Mohamed MK, El-Mas MM \& Abdel-Rahman AA. Estrogen enhancement of baroreflex sensitivity is centrally mediated. American Journal of Physiology 1999276 R1030-R1037.

16 El-Mas MM \& Abdel-Rahman AA. Estrogen enhances baroreflex control of heart rate in conscious ovariectomized rats. Canadian Journal of Physiology and Pharmacology 199876 381-386.

17 Alper RH \& Schmitz TM. Estrogen increases the bradycardia elicited by central administration of the $\operatorname{serotonin}_{1 \mathrm{~A}}$ agonists 8 OH-DPAT in conscious rats. Brain Research 1996716 224-228.

18 Henery C, Arsaut J, Arnauld E \& Demotes-Mainard J. Transient neonatal elevation in hypothalamic estrogen receptor mRNA in prenatally-stressed male rats. Neuroscience Letters 1996216 141-145.

19 Koike S, Sakai M \& Maramatsu M. Molecular cloning and characterization of the rat estrogen receptor cDNA. Nucleic Acids Research 198715 2499-2513.

20 Eaker ED, Chesebro JK, Sacks FM, Wenger NK \& Winston M. Cardiovascular disease in women. Circulation 199388 19992009.

21 Rosenkranz K, Hinney A, Ziegler A, Hermann H, Fichter M, Mayer H, Siegfried W, Young JK, Remschmidt H \& Hebebrand J. Systematic mutation screening of the estrogen receptor beta gene in probands of different weight extremes: identification of several genetic variants. Journal of Clinical Endocrinology and Metabolism 199883 4524-4527.

22 Yoo KY, Kim H, Shin HR, Kang D, Ha M, Park SK, Lee BO \& Cho SH. Female sex hormones and body mass in adolescent and postmenopausal Korean women. Journal of Korean Medical Science $199813241-246$.

23 Rosser M, Chorich L, Howard E, Zamorano P \& Mahesh VB. Changes in rat uterine estrogen receptor messenger ribonucleic 
acid levels during estrogen- and progesterone-induced estrogen receptor depletion and subsequent replenishment. Biology of Reproduction 199348 89-98.

24 Eisenfeld AJ, Aten R, Weinberger M, Haselbacher G \& Halpern K. Estrogen receptor in the mammalian liver. Science 1976191 862-865.

25 Kuipar GGJM, Carlquist M \& Gustafsson J-A. Estrogen is a male and female hormone. Science and Medicine 19985 36-45.

26 Ignatenko LL, Mataradze GD \& Rozen VB. Endocrine mechanisms for the formation of sex-related differences in hepatic estrogen receptor content and their significance for the realization of an estrogen effect on angiotensinogen blood level in rats. Hepatology 199215 1092-1098.

27 Shupnik MA, Gordon MS \& Chin WW. Tissue-specific regulation of rat estrogen receptor mRNAs. Molecular Endocrinology 19893 660-665.

28 Spano A, Sciola L, Pompucci G, Petruzzi V \& Pippia P. Estrogen receptor levels in the liver of intact and gonadectomized rats and in cultured hepatocytes. Bollettino-Societa Italiana Biologica Sperimentale 199167 1039-1046

29 Karas RH, Patterson BL \& Mendelsohn ME. Human vascular smooth muscle cells contain functional estrogen receptor. Circulation 199498 1943-1950.

30 Grohe C, Briesmeister G, Stimpel L, Karas RH, Vetter H \& Neyses L. Functional estrogen receptors in myocardial and myogenic cells. Circulation 199490 I-538.
31 Grohe C, Kahlert S, Lobbert K, Stimpel M, Karas RH, Vetter H \& Neyses L. Cardiac myocytes and fibroblasts contain functional estrogen receptors. FEBS Letters 1997416 107-112.

32 Proudler AJ, Ahmed AIH, Crook D, Fogelman I, Rymer JM \& Stevenson JC. Hormone replacement therapy and serum angiotensin-converting enzyme activity in postmenopausal women. Lancet $199534689-90$.

33 Kuiper G, Carlsson B, Grandien K, Enmark E, Haggblad J, Nilsson $\mathrm{S} \&$ Gustafsson J-A. Comparison of the ligand binding specificity and transcript tissue distribution of estrogen receptors $\alpha$ and $\beta$. Endocrinology 1997138 863-870.

34 Sar M \& Welsch F. Differential expression of estrogen receptor-beta and estrogen receptor-alpha in the rat ovary. Endocrinology 1999 140 963-971.

35 Shen ES, Hardenburg JL, Meade EH, Arey BJ, Merchenthaler I \& Lopez FJ. Estradiol induces galanin gene expression in the pituitary of the mouse in an estrogen receptor alpha-dependent manner. Endocrinology $19991402628-2631$.

36 Dubal DB, Shughrue PJ, Wilson ME, Merchenthaler I \& Wise PM. Estradiol modulates bcl-2 in cerebral ischemia: a potential role for estrogen receptors. Journal of Neuroscience 199919 63856393.

Received 21 June 1999

Accepted 26 October 1999 